\title{
Soy protein concentrate as a protein source for Senegalese sole (Solea senegalensis Kaup 1858) diets: effects on growth and amino acid metabolism of postlarvae
}

\author{
Cláudia Aragão ${ }^{1}$, Luis E C Conceição ${ }^{1}$, Jorge Dias ${ }^{2}$, Ana Clara Marques', Emídio Gomes ${ }^{2}$ \& Maria \\ Teresa Dinis ${ }^{1}$ \\ ${ }^{1}$ CCMAR, Universidade do Algarve, Faro, Portugal \\ ${ }^{2}$ CIIMAR, Universidade do Porto, Porto, Portugal
}

\begin{abstract}
The objective of this work was to evaluate the effect of a dietary amino acid imbalance, originating from the use of a soy protein concentrate (SPC) as the major protein source, on the growth performance and amino acid metabolism of Senegalese sole (Solea senegalensis) postlarvae. Senegalese sole $(85.6 \pm 24.6 \mathrm{mg}$ wet weight) were fed one of two experimental diets: one based on fish meal (FM) and another based on SPC. Diets were isonitrogenous (around 56\% crude protein) and isoenergetic. Diet acceptability was very good and the growth rate was $6.9 \%$ day $^{-1}$ for sole eating the FM diet and $6.0 \%$ day $^{-1}$ for sole eating the SPC diet. Mass-specific ammonia excretion and the activities of selected amino acid metabolic enzymes (ALAT, ASAT and GDH) did not present significant differences between treatments, although this may have been due to the high variability found for these parameters in the SPC treatment. This variability may suggest different capacities of individual fish to adapt to the possible methionine dietary deficiency. The utilization of amino acids as a substrate for lipogenesis does not seem to be affected by the dietary protein source, since NAPDH-generating enzymes (G6PD and ME) had similar activities in both treatments. Amino acid metabolism in Senegalese sole postlarvae seems to be slightly affected by the dietary protein source. Nevertheless, the changes induced by the SPC diet do not seem to impair growth, at least at the high dietary protein level used in this experiment.
\end{abstract}

Keywords: Solea senegalensis, soy protein concentrate, fish meal replacement, amino acid metabolism

\section{Introduction}

Fish have a high dietary protein requirement; therefore, when culturing carnivorous fish, protein usually accounts for $45-50 \%$ of feed dry matter (NRC 1993). Fish meal (FM) is the most common protein source for carnivorous marine finfish diets. Given the continuous growth of aquaculture production over the last few decades, the demand for FM is increasing, the price of this limited resource is rising, and this is also contributing to the depletion of the wild fisheries stock (Naylor, Goldburg, Primavera, Kautsky, Beveridge, Clay, Folke, Lubchenco, Mooney $\&$ Troell 2000). The use of alternative protein-rich vegetable ingredients would help to reduce the dependency on FM, which in turn could lower the feed prices. This will be a crucial factor for aquaculture sustainability.

Soybean meal is often considered to be the most suitable and stable supply of an alternative ingredient for replacing FM in commercial fish diets (Alexis \& Nengas 2001). However, soybean presents several antinutritional factors that may affect the digestion and absorption of nutrients (Refstie, Svihus, Shearer \& Storebakken 1999; Refstie, Korsøen, Storebakken, Baeverfjord, Lein \& Roem 2000). Thus, the choice of a proper soy protein source (especially for diets with 
a high protein content) is very important, since appropriate processing can eliminate or deactivate several antinutritional factors.

Soy protein concentrate (SPC) seems a promising protein source for fish diets. Antinutritional factors seem to be eliminated or deactivated in SPC (Kaushik, Cravedi, Lalles, Sumpter, Fauconneau \& Laroche 1995; Day \& Plascencia González 2000) and the apparent protein digestibility for several species is similar in SPC and in FM diets (Stickney, Hardy, Koch, Harrold, Seawright \& Massee 1996; Day \& Plascencia González 2000; Kissil, Lupatsch, Higgs \& Hardy 2000).

Several studies have been carried out in the last few years on the use of SPC in fish diets, and the results are contradictory. In seabream, there is an inverse relationship between growth and the dietary level of SPC, and growth is reduced even in diets with only 30\% FM replacement (Kissil et al. 2000). In turbot, growth and nutrient utilization are not affected until 25\% FM replacement by SPC (Day \& Plascencia González 2000). In rainbow trout, a decrease in growth performance was reported in fish fed diets with more than 50\% FM substitution by SPC (Stickney et al. 1996). Another study with rainbow trout reported no effects on growth performance and nutrient utilization when dietary FM was totally replaced by SPC (Kaushik et al. 1995). In most of these works, the SPC diets have been supplemented with amino acids, mainly methionine.

There is a general belief that when FM is incorporated at high levels into the diets, the probability of a dietary deficiency in indispensable amino acids (IAA) is rather small (Alexis \& Nengas 2001). Soy protein sources are known for their amino acid deficiency, especially in sulphur amino acids, when compared with FM (Alexis \& Nengas 2001). Several studies have been carried out in terms of amino acid supplementation of SPC diets (Refstie, Storebakken, Baeverfjord \& Roem 2001; Sveier, Nordås, Bege \& Lied 2001; Takagi, Shimeno, Hosokawa \& Ukawa 2001), and the results seem to vary according to fish size and the level of FM replacement.

Several parameters can be used to evaluate the physiological effects of amino acid imbalances, in order to better explain growth and protein retention results when different protein sources are used. Diets deficient in some IAA lead to increased oxygen consumption when compared with diets balanced in IAA (Kaczanowski \& Beamish 1996). Ammonia excretion allows a direct estimation of amino acid catabolism (Cowey \& Walton 1989), and together with oxygen consumption measurements, allows the estimation of ammonia quotient (AQ) values, which can be used for studying the partitioning of energy sources (van den Thillart \& Kesbeke 1978; Finn, Rønnestad \& Fyhn 1995; Finn, Fyhn, Henderson \& Evjen 1996). Intermediary metabolism enzyme activities can be used to elucidate how metabolic pathways are modulated by dietary changes (Cowey \& Walton 1989; Segner \& Verreth 1995).

The dietary protein requirement for Senegalese sole (Solea senegalensis) has not yet been determined, but the diets commonly used have 50-60\% crude protein, supplied by FM. As the interest in the intensification of aquaculture production of this species is increasing, it seems interesting to investigate the possible substitution of the dietary FM by a vegetable protein source. Since young fish stages are more sensitive to nutritional (and antinutritional) factors, it seems worthy to investigate if dietary FM replacement by vegetable meal will affect postlarval metabolism and growth.

The objective of this work was to test a SPC diet without amino acid supplementation to find out if the eventual amino acid imbalance of this protein source affected Senegalese sole postlarval growth. Oxygen consumption, ammonia excretion and the activity of some intermediary metabolism enzymes were also determined, in order to identify the possible changes in fish amino acid metabolism.

\section{Material and methods}

\section{Experimental diets}

Two experimental diets were prepared based on different protein sources: one was FM-based and the other was based on SPC. The experimental diets were formulated to be isonitrogenous and isoenergetic. The ingredients and proximate composition of diets are presented in Table 1. All the ingredients were finely ground $(<250 \mu \mathrm{m})$, mixed in a horizontal helix ribbon mixer (model Mano, 100-L capacity, CPM, San Francisco, CA, USA) and dry pelleted using a steamless pelleting machine (model C-300, CPM) fitted with a die of $1.5-\mathrm{mm}$ diameter. During the pelleting process, the temperature ranged from 50 to $70{ }^{\circ} \mathrm{C}$. After cooling at room temperature, the pellets were crumbled in a roller mill and sieved to obtain particles with graded diameters (0.5-1.0 and 1.0-1.4 mm), which were used according to changes in fish size. Diets were stocked at $4{ }^{\circ} \mathrm{C}$ throughout the entire experimental period. 
Table 1 Ingredients and proximate composition of experimental diets

\begin{tabular}{|c|c|c|}
\hline Ingredients (\%) & FM & SPC \\
\hline Fish meal LT & 73.5 & 8.0 \\
\hline Soy protein concentrate (Estrilvo 70$)^{*}$ & 0 & 60.0 \\
\hline $\mathrm{CPSP} \mathrm{G} \dagger$ & 6.0 & 0 \\
\hline CPSP 90‡ & 0 & 8.0 \\
\hline Fish oil & 8.0 & 15.0 \\
\hline Aquatex§ & 8.0 & 4.5 \\
\hline Vitamin C & 1.0 & 1.0 \\
\hline Vitamin E & 1.0 & 1.0 \\
\hline Vitamin $\uparrow$ and mineral $\|$ mixture & 2.5 & 2.5 \\
\hline \multicolumn{3}{|l|}{ Proximate composition (\% DM) } \\
\hline Dry matter (DM) (\%) & 95.1 & 95.0 \\
\hline Crude protein $(\mathrm{CP})$ & 56.0 & 57.2 \\
\hline Lipid & 19.1 & 15.8 \\
\hline Starch & 3.9 & 13.0 \\
\hline Ash & 14.8 & 9.2 \\
\hline Estimated gross energy $\left(\mathrm{MJ} \mathrm{kg}^{-1}\right)$ & 22.4 & 22.7 \\
\hline
\end{tabular}

$\mathrm{FM}=$ fish meal diet, $\mathrm{SPC}=$ soy protein concentrate diet.

*Estrilvo from Sopropêche, France: $63 \%$ CP, 2\% lipid.

†CPSP G (hydrolysed fish protein concentrate) from Sopropêche: $72 \% \mathrm{CP}, 22 \%$ lipid.

$\ddagger$ CPSP 90 (hydrolysed fish protein concentrate) from Sopropêche, Boulogne sur mer: $85 \% \mathrm{CP}, 10 \%$ lipid.

§Aquatex from Sopropêche: $23.7 \%$ CP, 1\% lipid, 50\% raw starch. ๑Vitamin mixture (IU or $\mathrm{mg} \mathrm{kg}^{-1}$ diet): retinol, $15000 \mathrm{IU}$; calciferol, $3000 \mathrm{IU}$; $\alpha$-tocopherol, $20 \mathrm{mg}$; sodium menadionine bisulphate, $5 \mathrm{mg}$; thiamin, $5 \mathrm{mg}$; riboflavin, $5 \mathrm{mg}$; calcium panthotenate, $10 \mathrm{mg}$; nicotinic acid, $100 \mathrm{mg}$; pyridoxine, $5 \mathrm{mg}$; folic acid, $2 \mathrm{mg}$; cyanocobalamin, $0.05 \mathrm{mg}$; biotin, $0.5 \mathrm{mg}$; ascorbic acid, $200 \mathrm{mg}$; para-aminobenzoic acid, $50 \mathrm{mg}$; inositol, $500 \mathrm{mg}$; choline chloride, $500 \mathrm{mg}$.

| Mineral mixture (mg or $\mathrm{g} \mathrm{kg}^{-1}$ diet): cobalt, $0.4 \mathrm{mg}$; copper, $5.0 \mathrm{mg}$; iron, $40.0 \mathrm{mg}$; fluorine, $1.0 \mathrm{mg}$; iodine, $0.6 \mathrm{mg}$; magnesium, $100.0 \mathrm{mg}$; manganese, $10.0 \mathrm{mg}$; selenium, $0.1 \mathrm{mg}$; zinc, $15.0 \mathrm{mg}$; calcium, $1.08 \mathrm{~g}$; phosphorus, $0.80 \mathrm{~g}$; potassium, $0.52 \mathrm{~g}$; $\mathrm{NaCl}, 0.40 \mathrm{~g}$.

Chemical composition analysis of the diets was carried out using the following procedures: dry matter after drying at $105^{\circ} \mathrm{C}$ for $24 \mathrm{~h}$; ash by combustion at $550{ }^{\circ} \mathrm{C}$ for $12 \mathrm{~h}$; crude protein $(N \times 6.25)$ by the micro-Kjeldahl method; fat by dichloromethane extraction (Soxhlet); and starch by the glucoamylase-glucose oxidase method (Thievend, Mercier \& Guilbot 1972). Diet samples were also analysed for free amino acid (FAA) and protein-bound amino acid (PAA) content. Samples for FAA analysis were homogenized in $0.1 \mathrm{M} \mathrm{HCl}$, centrifuged at $1500 \mathrm{~g}$ for $30 \mathrm{~min}$, and the supernatant was deproteinized by ultrafiltration. For PAA analysis, samples were hydrolysed in $6 \mathrm{M} \mathrm{HCl}$ at $108{ }^{\circ} \mathrm{C}$ over $24 \mathrm{~h}$ in nitrogenflushed glass vials. FAA and PAA were analysed by reversed-phase high-pressure liquid chromatography
(HPLC) in a Waters Pico-Tag amino acid analysis system, using norleucine as an internal standard. The resulting peaks were analysed with Breeze software (Waters, USA).

\section{Fish rearing and sampling}

The experiment was carried out at the University of Algarve facilities (Faro, Portugal). Senegalese sole postlarvae with $85.6 \pm 24.6 \mathrm{mg}$ (wet weight) were distributed in groups of 70 fish each into six plastic white trays $(23 \times 33 \mathrm{~cm}$; 4 -L volume). The trays were in a recirculating system and water was supplied at a rate of $8 \mathrm{Lh}^{-1}$. Water was maintained at a temperature of $21.4 \pm 0.8{ }^{\circ} \mathrm{C}$ and a salinity of $36 \mathrm{~g} \mathrm{~L}^{-1}$, and oxygen in the water was always above $85 \%$ saturation. A 12/12-h light/dark cycle was adopted.

Senegalese sole postlarvae were already weaned and adapted to a dry diet (Aglonorse, Norsildmel Innovation AS, Norway). Each experimental diet was randomly assigned to triplicate trays. Fish were fed in excess by automatic feeding devices continuously during $18 \mathrm{~h}$. The growth trial lasted for 3 weeks.

At the beginning of the experiment, 20 fish from the initial stock were measured, weighed and frozen for posterior dry weight, protein and lipid analysis.

Survival was monitored during the experiment and fish were counted at the end. Oxygen consumption and ammonia excretion were determined in 12-h fasted and in fed sole, and fish were frozen and freezedried afterwards for dry weight determinations. Ten sole from each tray were also individually frozen in liquid nitrogen and stored at $-80{ }^{\circ} \mathrm{C}$ for further analysis of activities of selected intermediary metabolism enzymes. All the other fish that survived were measured, weighed and frozen for posterior dry weight, protein and lipid analysis. The relative growth rate $\left(\mathrm{RGR}, \% \mathrm{DW}\right.$ day $\left.^{-1}\right)$ was calculated as RGR $=\left(e^{g}-1\right)$ $\times 100$, being $g=\left(\ln \mathrm{DW}_{t}-\ln \mathrm{DW}_{0}\right) t^{-1}$, where $\mathrm{DW}_{t}$ and $\mathrm{DW}_{0}$ are the final and initial dry weights, respectively, and $t$ is the duration of the trial. The condition factor was calculated as WW LT ${ }^{-3} \times 100$, whereWW is the wet weight of the fish and LT is the total length of the fish.

\section{Respirometry}

Oxygen consumption and ammonia excretion were determined by closed respirometry on groups of three fish using spherical glass vials of 300-mL-calibrated volumes as respirometers. Two replicates from each 
tray and three blanks were used. The measurements were conducted in light at a temperature of $20 \pm 0.5{ }^{\circ} \mathrm{C}$ and a salinity of $36 \mathrm{~g} \mathrm{~L}^{-1}$. Oxygen tension readings were performed after $1 \mathrm{~h} 30 \mathrm{~min}$ to $2 \mathrm{~h}$ of incubation using a Micro-Oxygen Electrode, model MI-730 (Microelectrodes, Bedford, NH, USA). Massspecific oxygen consumption (expressed as $\mu \mathrm{molg}$ $\mathrm{DW}^{-1} \mathrm{~h}^{-1}$ ) was calculated according to the formula:

$$
\mathrm{MO}_{2}=\Delta \mathrm{O}_{2}\left[\mathrm{O}_{2} \text { sat }\right] \mathrm{V}_{\mathrm{H}_{2} \mathrm{O}} \mathrm{DW}^{-1} \Delta \mathrm{t}^{-1}
$$

where $\Delta \mathrm{O}_{2}=(\mathrm{mV}$ blank $-\mathrm{mV}$ sample $) \mathrm{mV}$ saturation $^{-1}$; $\left[\mathrm{O}_{2}\right.$ sat] is the oxygen concentration in saturated water $\left(\mu \mathrm{mol} \mathrm{L}^{-1}\right)$, calculated according to the equation described by García \& Gordon (1992); $V_{\mathrm{H}_{2} \mathrm{O}}$ is the respirometer water volume; DW is the fish dry weight; and $\Delta t$ is the elapsed time in the respirometer.

Ammonia excretion was determined by sampling, in triplicate, $1 \mathrm{~mL}$ of water from each respirometer. Samples were immediately analysed following the method of Bower \& Holm-Hansen (1980). Mass-specific ammonia excretion (expressed as $\mu \mathrm{molg} \mathrm{DW}{ }^{-1} \mathrm{~h}^{-1}$ ) was calculated according to the following formula:

$$
\mathrm{MNH}_{4}^{+}=\Delta\left[\mathrm{NH}_{4}^{+}\right] \mathrm{V}_{\mathrm{H}_{2} \mathrm{O}} \mathrm{DW}^{-1} \Delta \mathrm{t}^{-1},
$$

where $\Delta\left[\mathrm{NH}_{4}^{+}\right]$is the difference in the total ammonia concentration between the blank and the sample water.

The AQ was calculated as the molar ratio between ammonia production and oxygen consumption (van den Thillart \& Kesbeke 1978).

\section{Analytical methods}

All frozen fish, except those for enzymatic analysis, were freeze-dried and weighed. Pooled samples of 20 fish each (from the initial stock and from final sampling) were homogenized in distilled water, freezedried, and used for total lipid analysis by the method of Bligh \& Dyer (1959) and total protein analysis by the method of Lowry (Lowry, Rosebrough, Farr \& Randall 1951) with the micro-modification of Rutter (1967).

Five fish per tray were individually analysed for selected amino acid metabolic enzyme activities. Samples were homogenized in ice-cold buffer $(30 \mathrm{mM}$ HEPES, $0.25 \mathrm{mM}$ sucrose, $0.5 \mathrm{mM}$ EDTA, $5 \mathrm{mM}$ $\mathrm{K}_{2} \mathrm{HPO}_{4}, 1 \mathrm{mM} \mathrm{DTT}$, pH 7.4), at a constant dilution (10 volumes of buffer per sample weight), using an UltraTurrax and centrifuged at $1000 \mathrm{~g}$ for $10 \mathrm{~min}$ at $4{ }^{\circ} \mathrm{C}$. The supernatant was sonicated and centrifuged again at $15000 \mathrm{~g}$ for $20 \mathrm{~min}$ at $4{ }^{\circ} \mathrm{C}$. Enzyme activ- ities were assayed on the supernatant at $37{ }^{\circ} \mathrm{C}$ using spectrophotometric procedures, alanine aminotransferase (ALAT) and aspartate aminotransferase (ASAT) using bioMérieux Enzyline kit, and glutamate dehydrogenase (GDH) using the following assay conditions: $175 \mathrm{mM}$ Tris, $100 \mathrm{mM}$ semi-carbazine, $1.1 \mathrm{mM}$ NAD, $1 \mathrm{mM}$ ADP, $5 \mathrm{mM}$ L-leucine, started by $100 \mathrm{mM}$ L-glutamic acid, and the reaction was monitored by following the synthesis of NADH at $340 \mathrm{~nm}$.

Determination of selected lipogenic enzyme activities was performed individually in the other five fish. Individual fish were homogenized in ice-cold buffer (0.02 M Tris-HCl, $0.25 \mathrm{M}$ sucrose, $0.1 \mathrm{M}$ sodium fluoride, $2 \mathrm{mM}$ EDTA, $0.01 \mathrm{M} \beta$-mercaptoethanol, $0.5 \mathrm{mM}$ phenyl methyl sulphonyl fluoride, $\mathrm{pH}$ 7.4), at a constant dilution (10 volumes of buffer per sample weight), using an UltraTurrax and centrifuged at $30000 \mathrm{~g}$ for $20 \mathrm{~min}$ at $4{ }^{\circ} \mathrm{C}$. Enzyme activities were assayed on the supernatant using spectrophotometric procedures: glucose-6-phosphate dehydrogenase (G6PD), at $30{ }^{\circ} \mathrm{C}$ according to Bautista, Garrido-Pereira \& Soler (1988), malic enzyme (ME), at $30{ }^{\circ} \mathrm{C}$ according to Ochoa (1955), and fatty acid synthetase (FAS), at $37{ }^{\circ} \mathrm{C}$ according to Chang, Seidman, Teebor \& Lane (1967) with the modifications of Chakrabarty \& Leveille (1968, 1969).

Enzyme activity units (IU), defined as micromoles of substrate converted to product per minute at assay temperature, are expressed per gram of soluble protein (specific activity). The soluble protein content of fish was determined on the homogenates by the method of Bradford (1976) using bovine serum albumin (BSA) as the standard.

\section{Statistical analysis}

Data were tested by one-way ANOva followed by Bonferroni lines or by Student's $t$-test. The results expressed as a percentage were previously arcsine transformed (Zar 1999). The significance level used was $P=0.05$. The coefficients of variation (CV) were calculated as (Zar 1999) standard deviation mean $^{-1} \times 100$.

\section{Results}

\section{Fish, diets and growth}

Data on the amino acid composition of the diets are given in Table 2. The SPC diet had a significantly lower content of protein-bound valine, methionine, 
Table 2 Free and protein-bound amino acid (AA) composition of experimental diets ( $\mathrm{g} \mathrm{AA} \mathrm{kg}^{-1}$ diet)

\begin{tabular}{|c|c|c|c|c|}
\hline \multirow[b]{2}{*}{ AA } & \multicolumn{2}{|c|}{ Protein-bound AA (PAA) } & \multicolumn{2}{|c|}{ Free AA (FAA) } \\
\hline & $\mathbf{F M}$ & SPC & $\mathbf{F M}$ & SPC \\
\hline Val & $15.6 \pm 0.7^{a}$ & $14.1 \pm 0.7^{\mathrm{b}}$ & $0.6 \pm 0.06$ & $0.5 \pm 0.06$ \\
\hline Leu & $17.8 \pm 1.1$ & $17.9 \pm 0.1$ & $0.4 \pm 0.06$ & - \\
\hline Ile & $12.7 \pm 0.7$ & $12.1 \pm 0.5$ & $0.5 \pm 0.03$ & - \\
\hline Phe & $5.5 \pm 0.8^{\mathrm{b}}$ & $8.1 \pm 0.9^{a}$ & $0.9 \pm 0.05$ & $0.8 \pm 0.18$ \\
\hline Trp & - & - & $1.4 \pm 0.12^{\mathrm{a}}$ & $0.5 \pm 0.02^{b}$ \\
\hline Thr & $15.9 \pm 0.8$ & $14.3 \pm 0.8$ & $0.4 \pm 0.03^{\mathrm{a}}$ & $0.2 \pm 0.03^{b}$ \\
\hline Met & $12.1 \pm 0.7^{\mathrm{a}}$ & $8.7 \pm 1.3^{\mathrm{b}}$ & $1.2 \pm 0.09^{\mathrm{a}}$ & $0.9 \pm 0.05^{b}$ \\
\hline Lys & $40.0 \pm 1.3^{\mathrm{a}}$ & $34.7 \pm 1.1^{\mathrm{b}}$ & $1.2 \pm 0.08^{\mathrm{a}}$ & $0.8 \pm 0.07^{b}$ \\
\hline $\operatorname{Arg}$ & $19.7 \pm 1.2$ & $19.4 \pm 0.5$ & $0.5 \pm 0.03$ & - \\
\hline His & $11.7 \pm 0.3$ & $11.4 \pm 0.7$ & - & - \\
\hline Tyr & $11.9 \pm 0.2$ & $11.5 \pm 0.5$ & $0.5 \pm 0.05$ & - \\
\hline Cys & $8.8 \pm 0.2$ & $7.3 \pm 1.1$ & $1.9 \pm 0.24$ & $2.4 \pm 0.15$ \\
\hline Gly & $14.2 \pm 0.5^{a}$ & $12.1 \pm 0.6^{\mathrm{b}}$ & $0.4 \pm 0.01$ & - \\
\hline Ala & $16.1 \pm 0.2^{\mathrm{a}}$ & $14.1 \pm 1.1^{\mathrm{b}}$ & $1.0 \pm 0.03^{\mathrm{a}}$ & $0.3 \pm 0.03^{b}$ \\
\hline Pro & $16.1 \pm 0.5$ & $16.7 \pm 1.6$ & $0.9 \pm 0.04$ & - \\
\hline Ser & $15.3 \pm 0.4$ & $15.8 \pm 1.0$ & $0.2 \pm 0.001$ & - \\
\hline Asn & - & - & $0.3 \pm 0.03$ & - \\
\hline Asp & $25.2 \pm 0.9$ & $25.9 \pm 1.2$ & $0.9 \pm 0.12^{\mathrm{a}}$ & $0.4 \pm 0.04^{b}$ \\
\hline Glu & $33.4 \pm 0.7$ & $36.3 \pm 0.9$ & $2.6 \pm 0.22^{\mathrm{a}}$ & $0.8 \pm 0.03^{b}$ \\
\hline Tau & - & - & $2.1 \pm 0.10^{\mathrm{a}}$ & $0.6 \pm 0.02^{b}$ \\
\hline Orn & - & - & $0.3 \pm 0.01$ & - \\
\hline Pser & - & - & $2.24 \pm 0.31^{b}$ & $3.5 \pm 0.39^{a}$ \\
\hline Aad & - & - & $1.5 \pm 0.10^{\mathrm{a}}$ & $0.4 \pm 0.02^{b}$ \\
\hline
\end{tabular}

$\mathrm{FM}=$ fish meal diet, $\mathrm{SPC}=$ soy protein concentrate diet.

Values are means $\pm \mathrm{SD}(n=3)$, and different letters in the same row indicate significant differences at $P<0.05$ between diets for PAA or FAA.

lysine, glycine and alanine than the FM diet. The relative difference was highest for methionine (less $40 \%$ in the SPC diet than in the FM diet) and lysine (less $15 \%$ in the SPC diet). Although no significant differences were found for cystine between treatments, the SPC diet has less $20 \%$ cystine than the FM diet. Several differences were also found between diets with respect to FAA content. The percentage of FAAs $\left(\right.$ calculated as FAA $\left.(\mathrm{FAA}+\mathrm{PAA})^{-1} \times 100\right)$ in the SPC diet was significantly lower than in the $\mathrm{FM}$ diet $(4.1 \pm 0.3 \%$ and $7.3 \pm 0.3 \%$ respectively), and several AAs were only found in the FM diet.

Sole postlarvae readily accepted both diets, and survival was high and very similar between treatments (around 88\%; Table 3). The growth performance of sole fed the two experimental diets is given in Table 3. Sole grew well on both diets: the specific growth rate for fish eating the FM diet was $6.9 \%$ day $^{-1}$ and for fish eating the SPC diet was $6.0 \%$ day $^{-1}$. After 3 weeks of experiment, fish eating the FM diet were an average heavier than fish eating the SPC diet, although the difference was not statistically significant (Table 3). The variation found within treatments was very high for this parameter (CV $=69 \%$ in the FM diet and $57 \%$ in the SPC diet). Furthermore, no significant differences were found for the condition factor $(1.0 \pm 0.1)$ between the two groups (Table 3).

Data on total protein and total lipid content at the beginning and end of the experiment are also given in Table 3. At the end of the experiment, fish fed both experimental diets had a slight, although not significant, increase in lipid content. No significant differences were found among treatments for protein or lipid content at the end of the trial.

\section{Respirometry}

Data on oxygen consumption are shown in Fig. 1. The mass-specific oxygen consumption did not vary significantly, either between treatments or between fasted and fed sole in the same treatment.

No significant differences were found in mass-specific ammonia excretion rates (Fig. 2) between treatments, and a high variability of the values was 
Table 3 Survival, growth performance, total protein and total lipid content of Solea senegalensis postlarvae fed a fish meal (FM) or a soy protein concentrate (SPC) diet for 3 weeks

\begin{tabular}{lcc}
\hline & FM & SPC \\
\hline Survival (\%) & $88.3 \pm 1.4$ & $88.9 \pm 3.0$ \\
Dry weight (DW) (mg) & & \\
$\quad$ Initial & $15.1 \pm 6.4$ & $15.1 \pm 6.4$ \\
$\quad$ Final & $60.9 \pm 41.8$ & $50.9 \pm 29.1$ \\
Relative growth rate (\% day ${ }^{-1}$ ) & 6.9 & 6.0 \\
Condition factor & $1.0 \pm 0.1$ & $1.0 \pm 0.1$ \\
Protein (\% DW) & & \\
$\quad$ Initial & $63.2 \pm 6.1$ & $63.2 \pm 6.1$ \\
$\quad$ Final & $66.1 \pm 4.9$ & $68.4 \pm 4.1$ \\
Lipids (\% DW) & & \\
$\quad$ Initial & $15.7 \pm 1.7$ & $15.7 \pm 1.7$ \\
$\quad$ Final & $20.3 \pm 2.7$ & $20.1 \pm 1.1$ \\
\hline
\end{tabular}

Values are means \pm SD.

Absence of superscripts within each row indicates no significant difference between treatments.

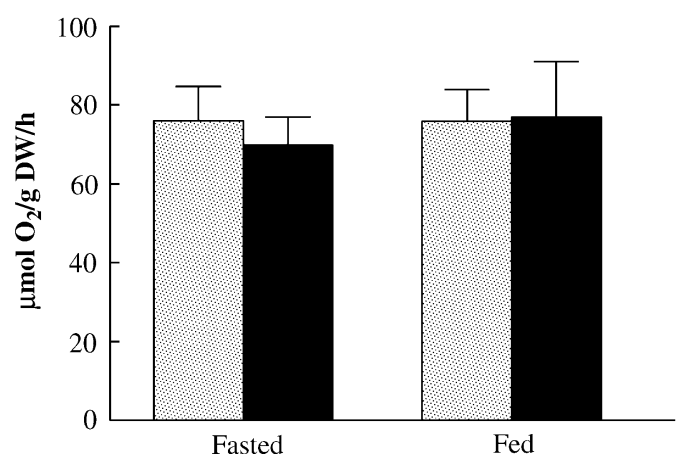

Figure 1 Mass-specific oxygen consumption of fasted and fed Solea senegalensis postlarvae, after 3 weeks of eating a fish meal (grey columns) or a soy protein concentrate diet (dark columns). Each column represents the mean \pm SD of six test measurements (two measurements per tank, three tanks per treatment), and the absence of letters indicates that no significant differences were found $(P>0.05)$.

observed, in particular, in the SPC diet $(\mathrm{CV}=60 \%)$ when compared with the FM diet $(\mathrm{CV}=33 \%)$. In the SPC treatment, no significantly differences in ammonia excretion were found between fasted and fed fish $\left(15.2 \pm 9.1\right.$ and $13.6 \pm 4.8 \mu \mathrm{mol} \mathrm{NH}_{4}^{+} \mathrm{g} \mathrm{DW}^{-1} \mathrm{~h}^{-1}$ respectively). Fed fish eating the FM diet had a significant lower ammonia excretion than fasted ones $\left(9.8 \pm 1.1\right.$ and $15.0 \pm 3.4 \mu \mathrm{mol} \mathrm{NH} \mathrm{g} \mathrm{DW}^{+1} \mathrm{~h}^{-1}$ respectively).

No significant differences were found in the $A Q$ of fasted and fed fish eating the SPC $\operatorname{diet}(0.21 \pm 0.11$ and

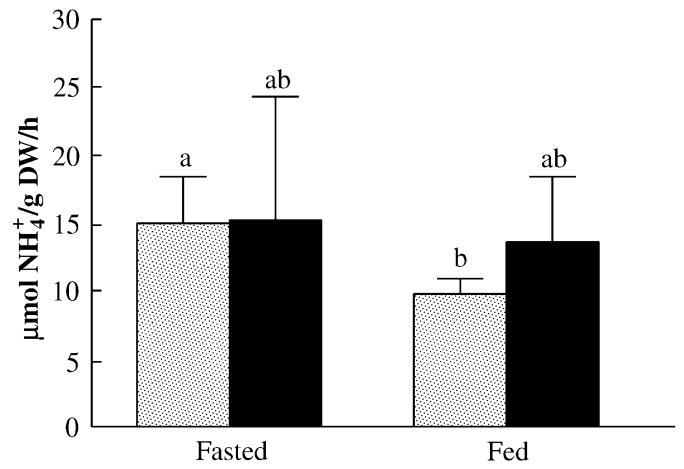

Figure 2 Mass-specific ammonia excretion of fasted and fed Solea senegalensis postlarvae, after 3 weeks of eating a fish meal (grey columns) or a soy protein concentrate diet (dark columns). Each column represents the mean \pm SD of six test measurements (two measurements per tank, three tanks per treatment), and different letters indicate significant differences at $P<0.05$.

Table 4 Specific activities (IU g ${ }^{-1}$ protein) of selected amino acid metabolic (ALAT, ASAT, GDH) and lipogenic (ME, G6PD, FAS) enzymes of Solea senegalensis postlarvae, after 3 weeks of eating a fish meal (FM) or a soy protein concentrate diet (SPC)

\begin{tabular}{llr}
\hline & FM & SPC \\
\hline $\begin{array}{l}\text { Alanine aminotransferase } \\
\text { (ALAT) }\end{array}$ & $153.8 \pm 63.7$ & $180.3 \pm 73.9$ \\
$\begin{array}{l}\text { Aspartate aminotransferase } \\
\text { (ASAT) }\end{array}$ & $651.7 \pm 282.4$ & $819.0 \pm 350.3$ \\
$\begin{array}{l}\text { Glutamate dehydrogenase } \\
\quad(G D H)\end{array}$ & $13.8 \pm 8.7$ & $16.4 \pm 9.0$ \\
$\begin{array}{l}\text { Malic enzyme (ME) } \\
\text { Glucose-6-phosphate }\end{array}$ & $5.8 \pm 2.5$ & $6.4 \pm 3.0$ \\
dehydrogenase (G6PD) & $31.7 \pm 6.8$ & $32.8 \pm 7.2$ \\
Fatty acid synthetase (FAS) & Not detected & Not detected \\
\hline
\end{tabular}

Each point represents the mean \pm SD of 15 individual postlarvae (five fish per tank, three tanks per treatment).

The absence of superscripts within each row indicates no significant differences between treatments.

$0.18 \pm 0.04$ respectively), and a high variability of the values was observed in the fasted fish $(\mathrm{CV}=54 \%)$ compared with fed fish $(\mathrm{CV}=23 \%)$. Fed fish eating the FM diet presented a significantly lower AQ than the fasted ones $(0.14 \pm 0.02$ and $0.20 \pm 0.05$ respectively).

\section{Enzymatic activities}

The results on the activities of amino acid metabolic enzymes are shown in Table 4. Enzyme activities 
were on average higher in the SPC treatment than in the FM treatment, although the differences were not statistically significant between treatments. A high variability of the values ( $\mathrm{CV}>40 \%$ ) was observed in the three enzymes analysed.

Table 4 also shows the lipogenic enzyme activities found for fish fed both diets. No apparent effect of protein source was detected on ME or G6PD activities. FAS activity was below the detection level in both treatments.

\section{Discussion}

When fish are fed a diet with a high FM replacement level by SPC, as is the case in this study, a reduction in diet acceptability was observed by several authors, and this was suggested to be due to a reduction in feed intake (Day \& Plascencia González 2000; Kissil et al. 2000). FAAs have been identified as attractants for several fish larvae and juveniles (Mackie, Adron \& Grant 1980; Knutsen 1992; Kolkovski, Arieli \& Tandler 1997). The lower FAA content of the SPC diet compared with the FM diet found in this study could result in the SPC diet being less attractive to Senegalese sole. In spite of this, Senegalese sole postlarvae accepted both diets very well, and it seems that a diet with a high inclusion level of SPC is not less attractive to these fish. The reduction in diet palatability with increasing SPC incorporation usually results in a decrease in feed consumption, which ultimately leads to a growth reduction (Day \& Plascencia González 2000; Kissil et al. 2000). In this study, no significant reduction in growth performance was noticed in sole fed the SPC diet. No significant differences were found between treatments with respect to the final weight, and although fish eating the SPC diet had a lower RGR than those eating the FM diet, this value was similar to the ones found in other studies using FM-based diets (Engrola, Conceição \& Dinis 2001).

The reduced growth performance generally found in fish fed SPC diets has also been attributed to a reduction in protein utilization (Day \& Plascencia González 2000; Kissil et al. 2000), which has been associated to a dietary amino acid deficiency. The amino acid analysis revealed that in the SPC diet, some PAAs were lower than in the FM diet, particularly the sulphur amino acids and lysine. Several authors have also found a lower methionine and lysine content in SPC diets than in FM diets (Kaushik et al. 1995; Day \& Plascencia González 2000; Takagi et al. 2001), and it has been shown that methionine supplementation to SPC diets improved the growth performance in young red seabream (Takagi et al. 2001). In spite of this, the growth of Senegalese sole does not seem to be impaired by the dietary methionine deficiency found in the SPC diet. It has been suggested that soybean meal could be used as a protein source in the formulation of compound feeds for this species with less restrictions than in other fish (Moyano López, Martínez Díaz, Díaz López \& Alarcón López 1999). Senegalese sole seem to be more resistant to some antinutritional factors present in soybean meal than other species, since digestive proteases are more resistant to the inhibitor present in soybean meal than, for instance, seabream or tilapia (Moyano López et al. 1999). In seabream, growth reductions were observed even when only 30\% dietary FM was replaced by SPC (Kissil et al. 2000).

A point that seems worth noticing is that the protein content in the diets used in this study was very high (around 56\%). This could also have masked some possible amino acid imbalance, since probably amino acids were provided in excess of what is needed for protein synthesis and therefore were not limiting growth. Since protein is the most expensive ingredient in diets for cultured species, there is a general tendency to decrease the protein level in the diets, in order to spare protein for growth and not waste it as a metabolic fuel. If this could be achieved in diets for sole, eventually dietary methionine may become limiting when using SPC diets.

The protein and lipid content of sole was not affected by the dietary protein source. Different effects were found for other species. A high dietary FM replacement by SPC increased the lipid content in salmonids (Kaushik et al. 1995; Sveier et al. 2001), while in seabream a reduction in the lipid content was observed (Kissil et al. 2000).

With respect to the results from oxygen consumption, it was found that this parameter did not vary between treatments or between fasted and fed fish. A post-prandial increase in oxygen consumption is usually found in fish and is associated with an increase in protein synthesis, leading to growth (Houlihan 1991; Jobling 1994). Since no post-prandial increase in oxygen consumption was found in this study, this may indicate that sole reduce the costs of maintenance to accommodate the costs of growth. A reduction in the costs of maintenance has also been suggested for larval whitefish and roach (Wieser \& Medgyesy 1990), chinook salmon (Rombough 1994) and juvenile African catfish (Conceição, Dersjant-Li \& Verreth 1998). This reduction is probably due to a 
suppression of some energy-consuming functions of maintenance, such as protein turnover, in order to allocate energy for growth (Wieser \& Medgyesy 1990). Whether or not this energy allocation is similar between treatments is not possible to determine.

The results from this experiment showed that the ammonia excretion was similar in both treatments. This was due essentially to the high variability found in fish eating the SPC diet, which may imply that some fish are more sensible to the possible dietary methionine deficiency than others, suggesting different capacities to adapt to this dietary deficiency.

In fish eating the SPC diet, no significant change in ammonia excretion after feeding was observed. The $\mathrm{AQ}$ results indicate that these fish have a metabolism that relies essentially on the catabolism of proteins, as when aerobic metabolism is solely based on the catabolism of proteins the AQ value is 0.27 (van den Thillart \& Kesbeke 1978).

In the FM diet, fasted fish had a higher ammonia excretion than fed fish. The basal ammonia excretion was reduced, suggesting that sole eating the FM diet catabolize more protein for energy purposes when fasted than after feeding, when they probably catabolize more non-protein energy and thereby spare amino acids for growth. This result is also supported by the significantly lower AQ found for the fed fish. According to the data from van den Thillart \& Kesbeke (1978), it is possible to calculate that $73 \%$ of the substrate catabolized for energy in fasted sole was protein, while after feeding this was reduced to $52 \%$. Still, the metabolic indications of protein sparing in fish fed the FM diets did not result in any apparent growth benefits. Although the high variability found in both treatments did not allow the detection of significant differences between them, a tendency for the fish eating the FM diet to be heavier than fish eating the SPC diet was noticed.

The amino acid metabolic enzyme activities in fish fed the SPC diet tend to be higher than in fish eating the FM diet. However, the high variability found in these enzyme activities did not permit the detection of significant changes between both treatments. Still, when observing the data, it is apparent that in some fish eating the SPC diet the transdeamination was increased, leading to a higher amino acid catabolism. This ultimately resulted in a higher variability in the ammonia excretion found for this treatment. Nevertheless, some other fish eating the SPC diet were able to maintain their catabolism at a level similar to that found in the FM treatment. This corroborates the sug- gestion made above that individual fish had different abilities to adapt to the possible methionine dietary deficiency.

After deamination, the carbon residues from amino acids may contribute to the acetyl-CoA pool and therefore play a significant metabolic role as a primary substrate for lipogenesis or gluconeogenesis (Moon \& Mommsen 1987). The mechanisms mediating the dietary protein quality modulation of de novo fatty acid synthesis are ill-defined, but the differences in the amino acid composition of the proteins and the levels of certain antinutritional factors have been cited as major factors (Herzberg 1991; Laraki, Pelletier, Mourot \& Debry 1993). Experiments with rainbow trout and European seabass have shown that G6PD and ME activities were depressed by SPC-rich diets (Dias 1999). On the contrary, in sole the dietary protein source does not seem to affect the utilization of amino acids as a substrate for lipogenesis, since the activities of the enzymes that generate NADPH for fatty acid synthesis (G6PD and ME) were very similar among treatments.

Liver is the primary organ for lipogenesis (Aster \& Moon 1981), and lipogenic enzyme activities are usually high in hepatic tissue (Lin, Romsos, Tack \& Leveille 1977; Likimani \& Wilson 1982). Due to the small weight of postlarval liver, it was decided to homogenize the whole fish for enzymatic analysis. This may have diluted the FAS activity to levels undetectable by the spectrophotometric method used, since FAS activity is usually much lower than G6PD or ME activities (Lin et al. 1977; Likimani \& Wilson 1982; Dias 1999).

In conclusion, although an SPC-based diet induced some changes in the amino acid metabolism of Senegalese sole postlarvae, it does not seem to impair growth, at least at the high dietary protein level used in this experiment. The mechanisms by which the dietary amino acid balance and/or antinutritional factor levels of vegetable proteins may affect the lipogenic pathway are still poorly understood, but are particularly worth exploring in fish, given the established trend for FM replacement in aquaculture diets.

\section{Acknowledgments}

This work was supported by project POCTI/1999/ CVT/34608 (FCT, Portugal, with the support of the European fund FEDER). Cláudia Aragão and Luis Conceição were supported by PRAXIS XXI Grants 
BD/18390/98 and BPD/7149/2001 (FCT, Portugal) respectively.

\section{References}

Alexis M.N. \& Nengas I. (2001) Current State of Knowledge Concerning the use of Soy Products in Diets for Feeding Sea Bass and Sea Bream. Needs for Future Research. American Soybean Association, Athens, Greece, 32 pp.

Aster P.L. \& Moon T.W. (1981) Influence of fasting and diet on lipogenic enzymes in the American eel, Anguilla rostrata LeSeur. Journal of Nutrition 111, 346-354.

Bautista J.M., Garrido-Pereira A. \& Soler G. (1988) Glucose6-phosphate dehydrogenase from Dicentrarchus labrax liver: kinetic mechanism and kinetics of NADPH inhibition. Biochimica et Biophysica ACTA 967, 354-363.

Bligh E.G. \& Dyer W.J. (1959) A rapid method of total lipid extraction and purification. Canadian Journal of Biochemistry and Physiology 37, 911-917.

Bower C.E. \& Holm-Hansen T. (1980) A salicylate-hypochlorite method for determining ammonia in seawater. Canadian Journal of Fisheries and Aquatic Sciences 37, 794-798.

Bradford M.M. (1976) A rapid and sensitive method for the quantitation of microgram quantities of protein utilizing the principle of protein-dye binding. Analytical Biochemistry 72, 248-254.

Chakrabarty K. \& Leveille G.A. (1968) Influence of periodicity of eating on the activity of various enzymes in adipose tissue, liver and muscle of the rat. Journal of Nutrition 96, 76-82.

Chakrabarty K. \& Leveille G.A. (1969) Acetyl-CoA-carboxylase and fatty acid synthetase activities in liver and adipose tissue of meal-fed rats. Proceedings of the Society for Experimental Biology and Medicine 131, 1051-1054.

Chang H.C., Seidman I., Teebor G. \& Lane D.M. (1967) Liver acetyl-CoA-carboxylase and fatty acid synthetase relative activities in the normal state and in hereditary obesity. Biochemical and Biophysical Research Communications $\mathbf{2 8}$, 682-686.

Conceição L.E.C., Dersjant-Li Y. \& Verreth J.A.J. (1998) Cost of growth in larval and juvenile African catfish (Clarias gariepinus) in relation to growth rate, food intake and oxygen consumption. Aquaculture 161, 95-106.

Cowey C.B. \& Walton M.J. (1989) Intermediary metabolism. In: Fish Nutrition (ed. by J.E. Halver), pp. 259-329. Academic Press, New York, USA.

Day O.J. \& Plascencia González H.G. (2000) Soybean protein concentrate as a protein source for turbot Scophthalmus maximus L. Aquaculture Nutrition 6, 221-228.

Dias J. (1999) Lipid deposition in rainbow trout (Oncorhynchus mykiss) and European seabass (Dicentrarchus labrax): nutritional regulation of hepatic lipogenesis. $\mathrm{PhD}$ thesis, Universidade do Porto, Porto, Portugal, 186 pp.

Engrola S., Conceição L.E.C. \& Dinis M.T. (2001) Effect of a pre-weaning feeding regime on weaning success of Solea senegalensis. In: Larvi'O1 - Fish and Shellfish Larviculture Symposium (ed. by C.J. Hendry, G. Van Stappen, M. Wille \& P. Sorgeloos), pp. 178-181. Special Publication No. 30. European Aquaculture Society, Ghent, Belgium.

Finn R.N., Fyhn H.J., Henderson R.J. \& Evjen M.S. (1996) The sequence of catabolic substrate oxidation and enthalpy balance of developing embryos and yolk-sac larvae of turbot (Scophthalmus maximus L.). Comparative Biochemistry and Physiology Part A 115, 133-151.

Finn R.N., Rønnestad I. \& Fyhn H.J. (1995) Respiration, nitrogen and energy metabolism of developing yolc-sac larvae of Atlantic halibut (Hippoglossus hippoglossus L). Comparative Biochemistry and Physiology Part A 111, 647-671.

García H.E. \& Gordon L.I. (1992) Oxygen solubility in seawater: better fitting equations. Limnology and Oceanography 37, 1307-1312.

Herzberg G.R. (1991) The 1990 Borden award lecture. Dietary regulation of fatty acid and triglyceride metabolism. Canadian Journal of Physiology and Pharmacology 69, 1637-1647.

Houlihan D.F. (1991) Protein turnover in ectotherms and its relationships to energetics. In: Advances in Comparative and Environmental Physiology (ed. by R. Gilles), pp. 1-43. Springer-Verlag, Berlin, Germany.

Jobling M. (1994) Fish Bioenergetics. Chapman \& Hall, London, UK, 309 pp.

Kaczanowski T.C. \& Beamish F.W.H. (1996) Dietary amino acids and heat increment in rainbow trout (Onchorhyncus mykiss). Fish Physiology and Biochemistry 15, 105-120.

Kaushik S.J., Cravedi J.P., Lalles J.P., Sumpter J., Fauconneau B. \& Laroche M. (1995) Partial or total replacement of fish meal by soybean protein on growth, protein utilization, potential estrogenic or antigenic effects, cholesterolemia and flesh quality in rainbow trout, Oncorhynchus mykiss. Aquaculture 133, 275-274.

Kissil G.W., Lupatsch I., Higgs D.A. \& Hardy R.W. (2000) Dietary substitution of soy and rapeseed protein concentrates for fish meal, and their effects on growth and nutrient utilization in gilthead seabream Sparus aurata L. Aquaculture Research 31, 595-601.

Knutsen J.A. (1992) Feeding behaviour of North Sea turbot (Scophthalmus maximus) and Dover sole (Solea solea) larvae elicited by chemical stimuli. Marine Biology 113, 543-548.

Kolkovski S., Arieli A. \& Tandler A. (1997) Visual and chemical cues stimulate microdiet ingestion in sea bream larvae. Aquaculture International 5, 527-536.

Laraki L., Pelletier X., Mourot J. \& Debry G. (1993) Effects of dietary phytosterols on liver lipids and lipid metabolism enzymes. Annals of Nutrition and Metabolism 37, 129-133.

Likimani T. \& Wilson R.P. (1982) Effects of diet on lipogenic enzyme activities in channel catfish hepatic and adipose tissue. Journal of Nutrition 112, 112-117. 
Lin H., Romsos D.R.,Tack P.I. \& Leveille G.A. (1977) Influence of dietary lipid on lipogenic enzyme activities in coho salmon, Oncorhynchus kisutch (Walbaum). Journal of Nutrition 107, 846-854.

Lowry O.H., Rosebrough N.J., Farr A.L. \& Randall R.J. (1951) Protein measurement with the folin phenol reagent. Journal of Biological Chemistry 193, 265-275.

Mackie A.M., Adron J.W. \& Grant P.T. (1980) Chemical nature of feeding stimulants for the juvenile Dover sole, Solea solea (L.). Journal of Fish Biology 16, 701-708.

Moon T.W. \& Mommsen T.P. (1987) Enzymes of intermediary metabolism in tissues of the little skate, Raja erinacea. Journal of Experimental Zoology 244, 9-15.

Moyano López F.J., Martínez Díaz I., Díaz López M. \& Alarcón López F.J. (1999) Inhibition of digestive proteases by vegetable meals in three fish species; seabream (Sparus aurata), tilapia (Oreochromis niloticus) and African sole (Solea senegalensis). Comparative Biochemistry and Physiology Part B 122, 327-332.

Naylor R.L., Goldburg R.J., Primavera J.H., Kautsky N., Beveridge M.C.M., Clay J., Folke C., Lubchenco J., Mooney H. \& Troell M. (2000) Effect of aquaculture on world fish supplies. Nature 405, 1017-1024.

NRC (1993) Nutrient Requirements of Fish. National Academy Press, Washington, DC, USA, 114 pp.

Ochoa S. (1955) Malic enzyme. In: Methods in Enzymology (ed. by S.P. Colowick \& N.O. Kaplan), pp. 739-753. Academic Press, New York, USA.

Refstie S., Korsøen Ø.J., Storebakken T., Baeverfjord G., Lein I. \& Roem A.J. (2000) Differing nutritional responses to dietary soybean meal in rainbow trout (Oncorhynchus mykiss) and Atlantic salmon (Salmo salar). Aquaculture 190, 49-63.

Refstie S., Storebakken T., Baeverfjord G. \& Roem A.J. (2001) Long-term protein and lipid growth of Atlantic salmon (Salmo salar) fed diets with partial replacement of fish meal by soy protein products at medium or high lipid level. Aquaculture 193, 91-106.

Refstie S., Svihus B., Shearer K.D. \& Storebakken T. (1999) Nutrient digestibility in Atlantic salmon and broiler chickens related to viscosity and non-starch polysacchar- ide content in different soyabean products. Animal Feed Science and Technology 79, 331-345.

Rombough P.J. (1994) Energy partitioning during fish development: additive or compensatory allocation of energy to support growth? Functional Ecology 8, 178-186.

Rutter W.J. (1967) Protein determinations in embryos. In: Methods in Developmental Biology (ed. by F.H. Witt \& N.K. Wessels), pp. 671-684. Academic Press, New York, USA.

Segner H. \& Verreth J. (1995) Metabolic enzyme activities in larvae of the African catfish, Clarias gariepinus: changes in relation to age and nutrition. Fish Physiology and Biochemistry 14, 385-398.

Stickney R.R., Hardy R.W., Koch K., Harrold R., Seawright D. \& Massee K.C. (1996) The effects of substituting selected oilseed protein concentrates for fish meal in rainbow trout Oncorhynchus mykiss diets. Journal of the World Aquaculture Society 27, 57-63.

Sveier H., Nordås H., Bege G.E. \& Lied E. (2001) Dietary inclusion of crystalline D- and L-methionine: effects on growth, feed and protein utilization, and digestibility in small and large Atlantic salmon (Salmo salar L.). Aquaculture Nutrition 7, 169-181.

Takagi S., Shimeno S., Hosokawa H. \& Ukawa M. (2001) Effect of lysine and methionine supplementation to a soy protein concentrate diet for red sea bream Pagrus major. Fisheries Science 67, 1088-1096.

Thievend P., Mercier C. \& Guilbot A. (1972) Determination of starch with glucoamylase. In: Methods in Carbohydrate Chemistry (ed. by R.L. Whistler \& J.N. Bemiller), pp. 100105. Academic Press, New York, USA.

van den Thillart G. \& Kesbeke F. (1978) Anaerobic production of carbon dioxide and ammonia by goldfish Carassius auratus (L.). Comparative Biochemistry and Physiology Part A 59, 393-400.

Wieser W. \& Medgyesy N. (1990) Cost and efficiency of growth in the larvae of two species of fish with widely differing metabolic rates. Proceedings of the Royal Society of London Series B 242, 51-56.

Zar J.H. (1999) Biostatistical Analysis. Prentice Hall International Editions, Illinois, USA, 662 pp. 